\title{
THE PROGRESS OF HELMINTHOLOGY IN THE U.S.S.R.
}

\author{
By G. M. VEVERS, M.R.C.S., L.R.C.P. \\ (Superintendent, Zoological Society of London; Convener, Supplies Sub-Committee of the \\ Anglo-Soviet Medical Committee ; Editor, Anglo-Soviet Journal.)
}

Among the various branches of medical and veterinary science which have advanced with amazing rapidity in the U.S.S.R. during the comparatively short space of time since the October Revolution in I9I7 is that of helminthology.

The name of Academician Skryabin is intimately associated with the advance in this field of medicine. In March, I94I, he was awarded a Stalin Prize for his outstanding work and for the many scientific papers which he has written.

In Czarist times it was a difficult matter for a student of human or veterinary medicine to obtain any information whatsoever on the subject of helminthology. All this was changed in I9I7, when on Skryabin's initiative the first faculty of parasitology was opened in the Novocherkassk State Veterinary Institute. Skryabin was the first professor of this new faculty. In ensuing years similar faculties were opened in all the higher veterinary schools of the Union.

The nature of the instruction provided on the subject of helminthology accordingly changed. The students of these institutes no longer received scrappy, scattered and desultory bits of information on helminthiasis, they received an integrated and scientific conception of the multitude of parasitic helminths and their inter-relations with the organism of the host. New methods of combating the principal forms of helminthiasis in livestock were also taught. As a result of this widespread teaching, veterinary graduates were able to make extensive use of their knowledge of helminthology in their practical work, and in addition carry on research both on the intricate life histories of parasites and new methods of treatment.

In the past twenty years Academician Skryabin has written over 400 scientific papers and books on his subject, including several text-books for higher and secondary schools. During this period he and his colleagues have established the existence of, and classified, over 500 species of helminths formerly unknown to science. Thanks to Skryabin, over 200 special helminthological expeditions, covering the whole of the U.S.S.R. from Novaya Zemlaya in the north to Turkmenistan in the south and from Belorussia in the west to the island of Sakhalin in the east, have been organised and have brought back results which have revolutionized the study of helminthology and played a most important part in improving the health both of the population and livestock throughout the country.

The Soviet school of helminthology regards helminthiasis in man as a social disease, affecting the physical and intellectual development of children and reducing the efficiency of adults. Likewise, amongst domestic livestock it has a deleterious effect upon the economic productivity of animals, increases sterility and reduces their powers of resistance to infection, thereby raising the death-rate.

Skryabin is an enthusiastic adherent of the prophylactic school. He has developed facilities for early diagnosis of helminthiasis in man and animals throughout the Soviet Union and has formulated a rational plan of sanitary and hygienic measures in order to eliminate the infective forms of helminths before they invade and come to maturity in the body of the definitive host. In carrying out this ideal, inspection of foodstuffs, hygienic water supplies, proper sewage systems, domestic sanitation, the planned alternation of pastures, and above all, the medical and veterinary education of the population in relation to helminthological science, has played an important part.

A large institute of veterinary helminthology in Moscow has been named after Skryabin and this is the centre of teaching and study of the subject. Connected with it is a network of helminthological institutes. Medical helminthology is directed by the helminthological department of the Martsinovsky Central Institute of Malaria and Tropical Diseases in Moscow. Like the veterinary institute, this is linked up with numerous helminthological departments in tropical diseases institutes throughout the Soviet Union. 